\title{
Status of Production and Distribution of Fresh Milk by Villagers in Bariyarpatti, Sohpur
}

\author{
Sitaram Chamlagain \\ Lecturer \\ Faculty of Management \\ M.M.A.M. Campus, Biratnagar, TU, Nepal \\ sitaramchamalagain72@gmail.com \\ $\&$ \\ Tulasa Dahal \\ Instructor \\ Nursing Campus, IOM, Biratnagar, Nepal \\ tulasadaha115@gmail.com
}

\begin{abstract}
The study specially focused on production and distribution of fresh milk in 'Bariyapatti' Rural Municipality, Sohapur village, where number of local people visit daily in order to buy fresh milk. Milk is good for the bones because it offers a rich source of calcium, a mineral essential for healthy bones and teeth. It reduces blood pressure which also benefits bone health. The main objective of the study is to explore and analyze the status of production and distribution of fresh milk by villagers in Bariyarpatti Rural Municipality ward No.- 04, Sohpur. The study is based on descriptive research design. Primary data collection tools i.e. observation, questionnaire method and direct interview method is used. The study concludes that the milk supplier of the village are facing the problem of supply fluctuation due to the improper management of milk production by villagers and selling situation of fresh milk. The trading place for trading milk is not appropriate. Despite large number of cows and buffalo populations, the proportion of milking animals has remained low, indicating a large number of 'unproductive' animals. The existing suppliers are not focusing on quality of milk, the quality of milk refers that they mix water with the fresh milk. Through improving in timely collecting money, considering hygiene factors and using cows to produce milk rather than buffalos can benefit for the supplier of milk.
\end{abstract}

Keywords: fresh milk, production, distribution, villagers, rural area.

\section{Introduction}

\subsection{Background}

Livestock is an integral component of farming systems in Nepal; it contributes about $12.8 \%$ to the total national gross domestic product (GDP) and 31.5\% to the agricultural GDP. It is 
estimated that the livestock share of agricultural GDP will reach $45 \%$ by the end of 20 years of the Agricultural Perspective Plan (APP) programme that is by fiscal year 2014/15. The major components of livestock GDP are milk and milk products from buffalo and cattle (32.7\% and $24.7 \%$ respectively). At present, the total annual milk production of Nepal is just over one million tonnes ( $70 \%$ from buffalo and $30 \%$ from cattle). Based on this figure, the per capita milk consumption over the country is about approximately $130 \mathrm{ml}$ per day. The average growth rate of milk production from 1985 to 1995 was $2.4 \%$ and the population growth rate $2.9 \%$. This gap is likely to increase in the future unless serious efforts are made to improve dairy production and marketing. In this chapter, we discuss the current characteristics of the dairy sector, its constraints, and opportunities for development, (Banskota 2015).

Sohpur village is located at Bariyarpatti rural municipality, ward No.-04 Siraha district, Nepal. A village is a clustered human settlement or community, larger than a town, with population ranging from a few hundred to a few thousand. Though villages are often located in rural areas the term urban village is also applied to certain urban neighborhoods. Most of the people in the village are producing agricultural product, like Crops, Fruits, Milk, and Vegetables etc. Of the several items are offering for sales at the village, the present study has selected only an analysis of milk production by villagers and selling situation of the village. Milk is a white liquid produced by the mammary glands of mammals. All mammals, including humans, will normally produce milk to feed their offspring until they are ready for solid food. It contains valuable nutrients, and it can offer a range of health benefits. Milk offers a rich source of calcium, a mineral essential for healthy bones and teeth. It reduces blood pressure which also benefits bone health. The major reason for selecting this place is that the researcher is more familiar with the environment due to researcher birth place so, the activities of the place can be frequently observed.

\subsection{Problem Problems}

The problem of the study is presented by raising the following research questions.

- What is the production status of milk production at Bariyarpatti-04, Sohpur.

- Is there short supply of fresh milk in relation to its demand?

- What are the problems of milk production and selling situation at the selected area?

\subsection{Research Objectives}

The main objective of the study is to explore and analyze the status of production and distribution of fresh milk by villagers in Bariyarpatti Rural Municipality ward No.-04, Sohpur. Specific objectives of this study are as below:

- To analyze the milk's demand and supply status of fresh milk at Bariyarpatti-04, Sohpur. 
- To identify some of the major problems of milk production and selling situation at the Bariyarpatti-04, Sohpur.

\subsection{Limitations of the Study}

The studies have some limitation are as follows:

- The present study is limited to Bariyarpatti-04, Sohpur area only.

- The present study considers only milk production and selling. No study of other agricultural product supply by the village.

- Large sample are not taken due to limited time availability and cost constraints for study.

\subsection{Rationale of the Study}

Milk is necessarily consumed by almost all Nepalese people either they are vegetarian or nonvegetarian. In this reference present study makes, an attempt to highlight the importance of milk production and selling in rural area.

\subsection{Literature Review}

Khanal, (2015) stated in his report study entitled "Situation of Milk production in Nepal" The study was based on secondary sources of data and information collection from data supply by DDC (Dairy Development Corporation). Nepal has a large dairy animal population with 7.09 million cattle and 4.49 million buffalos with very low annual average productivity with 670 liter/milking animal (438 liter/milking cow and 854 liter/milking buffalo). The major Findings of the study were the consumption and supply of milk products in early days when there were no organized dairies, demand of milk was fulfilled by raising cows or buffaloes by the people themselves. But after the establishment of DDC, the scenario began to gradually change with the increase supply of pasteurized milk and modern dairy products such as cheese, butter, ice cream etc. The latest milk production data of Nepal shows that 1,388,730 metric ton of milk with cow milk 400,950 metric ton (28.87 percent) and buffalo milk 987,780 metric ton (71.13 percent) has been produced in $2007 / 08$. Of this volume, only about 10 percent of milk $(138,873$ metric ton) is estimated of being used by the formal sector dairies.

India is endowed with a largest livestock population in the world having a total bovine population of 304 million compared to the world's total bovine population of 1400 million. It accounts for $57.3 \%$ of the world's buffalo population and $14.7 \%$ of the cattle population. There has been a major improvement in milk production, which increased from 17 million tonnes in 1951 to 127.9 million tonnes during 2011-12. The per capita availability of the milk has reached a level of 290 grams per day during the year 2011-12, which is more than the world 
average of 284 grams per day. Most of the milk in the country is produced by small, marginal farmers and landless laborers.

In order to meet the rapidly growing demand for milk with a focus to improve milky animal productivity and increase milk production, the Government of India has approved National Dairy Plan Phase-I (NDP-I) in February, 2012 with a total investment of about Rs.2242 crore to be implemented from 2011-12 to 2016-17. NDP-I will help to meet the projected national demand of 150 million tons of milk by 2016-17 from domestic production through productivity enhancement, strengthening and expanding village level infrastructure for milk procurement and provide producers with greater access to markets.

\section{Methods and Materials}

The study is based on descriptive research design. Stratified random sampling technique was taken to collect data for research purpose. In this study samples are those people who produce fresh milk and sell to other and the sample size was 40 people. Primary data are collected directly through suppliers of fresh milk at the area. Suppliers were asked to fill up series of questions, which contains multiple-choice questions. Though research contains purely primary data analysis, secondary sources like reports, journals, articles, internet etc. were used for the purpose of literature review. To analyze the data, Microsoft Excel has been used.

\section{Results and Discussion}

\subsection{Number of Families of each Caste}

Sohpur village is located at Bariyarpatti Rural Municipality, Siraha, Nepal. Most of the people in the village are producing agricultural product, like Crops, Fruits, Milk, and Vegetables etc. People of different cast families who are involved in the fresh milk production and distributions.

Table 1

Number of families of each caste

\begin{tabular}{lll}
\hline Name of cast & Number of family & In percentage \\
\hline Yadav & 123 & $32.3 \%$ \\
Mandal & 140 & 36.7 \\
Singh/Danuwar & 50 & 13.1 \\
Sharma/Thakur & 29 & 7.6 \\
Sah & 8 & 2.1 \\
Mochi/Chamar & 10 & 2.6 \\
Rai & 21 & 5.5 \\
\hline Total & 381 & 100 \\
\hline
\end{tabular}

Sources. Field survey, 2019. 
Table 1 represents that there are all together 381 individual families in the selected area belonging from different cast. In the table the first column show the various casts, the second column shows number of family and the third column shows the percentage of the families belonging from those castes. Mandals has the highest number (36.7\%) of the total production.

\subsection{Daily Production, Sales and Consumption of Fresh Milk}

People of different cast families who are involved in the milk daily production, sales and selfconsumption in liters.

Table 2

Daily production, sales and consumption of fresh milk

\begin{tabular}{llllll}
\hline Name of cast & $\begin{array}{c}\text { Number of } \\
\text { cow/ } \\
\text { buffalos }\end{array}$ & $\begin{array}{c}\text { No. of milking } \\
\text { cow/buffalos }\end{array}$ & $\begin{array}{c}\text { Production in } \\
\text { liter }\end{array}$ & $\begin{array}{c}\text { Sales in } \\
\text { liter }\end{array}$ & $\begin{array}{c}\text { Self- } \\
\text { consumption } \\
\text { in liter }\end{array}$ \\
\hline Yadav & 82 & 34 & 204 & 112 & 92 \\
Mandal & 87 & 14 & 70 & 45 & 24 \\
Singh/Danuwar & 2 & 0 & 0 & 0 & 0 \\
Sharma/Thakur & 6 & 3 & 12 & 7 & 5 \\
Sah & 0 & 0 & 0 & 0 & 0 \\
Mochi/Chamar & 2 & 1 & 4 & 3 & 1 \\
Rai & 6 & 2 & 6 & 4 & 2 \\
\hline Total & 185 & 54 & 296 & 171 & 124 \\
\hline
\end{tabular}

Sources. Field survey, 2019.

The table 2 shows that the total number of cow and buffalos are 185, apart from those only 54 cows/ buffalos provide fresh milk. The forth column, fifth column and sixth column shows total production, sales, self-consumption (in liter) of the day respectively.

\subsection{Short supply of Fresh Milk}

People who are involved in the fresh milk supply in the study area:

Table 3

Short supply of fresh milk

\begin{tabular}{lll}
\hline Response & Number of respondents & Percentage \\
\hline Yes & 19 & $95 \%$ \\
No & 1 & $5 \%$ \\
\hline Total & 20 & $100 \%$ \\
\hline
\end{tabular}

Sources. Field survey 2019. 
The result of various milk suppliers on short supply of milk is shown with the help of above table 3 . Out of total respondents, $95 \%$ of total respondents agree with the short supply of milk during some time period while remaining, $5 \%$ haven't faced any problem of short supply of fresh milk till the date.

\subsection{Frequency of short supply of Fresh Milk on Morning}

Farmers' frequency in the fresh milk supply on morning time in the study area.

Table 4

Frequency of short supply of fresh milk on morning

\begin{tabular}{lll}
\hline Frequency of short supply & Number of respondents & Percentage \\
Daily & 16 & $80 \%$ \\
Thrice in a week & 2 & $10 \%$ \\
Twice in week & 1 & $5 \%$ \\
Once in a week & 0 & 0 \\
Rarely & 1 & $5 \%$ \\
Total & 20 & $100 \%$ \\
\hline
\end{tabular}

Sources. Field survey 2019.

With the help of table 4, the frequency of short supply of fresh milk has been shown. Out of the total respondents, $80 \%$ of respondents has faced problems of short supply daily, $10 \%$ thrice in a week, $5 \%$ twice in a week, $0 \%$ once in a week and 5\% people has faced the problem rarely in morning.

\subsection{Frequency of short supply of Fresh Milk on Evening}

Farmers' frequency in the fresh milk supply on evening time in the study area.

Table 5

Frequency of short supply of fresh milk on evening

\begin{tabular}{lll}
\hline Frequency of short supply & Number of respondents & Percentage \\
Daily & 8 & $40 \%$ \\
Thrice in a week & 3 & $15 \%$ \\
Twice in week & 5 & $25 \%$ \\
Once in a week & 3 & $15 \%$ \\
Rarely & 1 & $5 \%$ \\
Total & 20 & $100 \%$ \\
\hline
\end{tabular}

Sources. Field survey 2019. 
With the help of table 5, the frequency of short supply of fresh milk has been shown. Out of the total respondents, $40 \%$ of respondents has faced problems of short supply daily, $15 \%$ thrice in a week, $25 \%$ twice in a week, $15 \%$ once in a week and $5 \%$ people has faced the problem rarely on evening

\subsection{Availability of Cold Store of Milk}

Availability of cold store for the milk storage facility for any special occasion or festivals in the study area.

Table 6

Availability of cold store of milk

\begin{tabular}{lcc}
\hline Response & No. of respondents & Percentage \\
Yes & 2 & $10 \%$ \\
No & 18 & $90 \%$ \\
Total & 20 & $100 \%$ \\
\hline
\end{tabular}

Sources. Field survey 2019.

Table 6 showed the number and percentage of milk supplier having cold storage facility for any special occasion or festivals. Among the total respondents $90 \%$ of respondents have not got any cold storage facility for keeping stock of milk while $10 \%$ of respondents have got the cold storage facility.

\subsection{Local Demand of Fresh Milk}

Demand of fresh milk for selling in the local area:

Table 7

Local demand of fresh milk

\begin{tabular}{lcl}
\hline Response & Respondents & percentage \\
High & 11 & $55 \%$ \\
Low & 4 & $20 \%$ \\
Moderate & 5 & $25 \%$ \\
Total & 20 & $100 \%$ \\
\hline
\end{tabular}

Sources. Field survey 2019.

Table 7 present the local demand of fresh of milk in market. Among them 55\% of respondents response on high, $25 \%$ response on moderate and 20\% response on low.

\subsection{Number of Customer Visiting Market Daily}

Customers who visit daily for consume fresh milk from local market. 
Table 8

Number of customer visiting market daily

\begin{tabular}{lcl}
\hline Number of customer & Number of respondents & Percentage \\
\hline 1 to 3 & 12 & $60 \%$ \\
3 to 5 & 5 & $25 \%$ \\
5 to 7 & 3 & $15 \%$ \\
7 and above & 0 & $0 \%$ \\
\hline otal & 20 & $100 \%$ \\
\hline
\end{tabular}

Sources. Field survey, 2019.

The table 8 shows the total number of customer visiting this market daily. Out of total respondents $60 \%$ people responded as 1 to $3,25 \%$ people responded as 3 to $5,15 \%$ people responded as 5 to 7 and none of them has responded on 7 and above.

\subsection{Seller Satisfaction on Trading Area}

Frequency of seller satisfaction regarding the trading area.

Table 9

Seller satisfaction on trading area

\begin{tabular}{lcl}
\hline Response & No. of respondents & Percentage \\
Yes & 2 & $10 \%$ \\
No & 18 & $90 \%$ \\
\hline Total & 20 & $100 \%$ \\
\hline
\end{tabular}

Sources. Field survey, 2019.

Table 9 describe the frequency of seller satisfaction regarding the trading area, $90 \%$ trader responded dissatisfaction regarding trading area remaining $10 \%$ satisfied with the trading.

\subsection{Collection of Milk for Sales}

Sources from where the fresh milk are bought and sold in local market.

Table 10

Collection of milk for sales

\begin{tabular}{lcc}
\hline Response & No. of respondents & Percentage \\
Own source & 20 & $100 \%$ \\
Others & 0 & 0 \\
\hline Total & 20 & $100 \%$ \\
\hline
\end{tabular}

Sources. Field survey 2019. 
Table 10 shows the sources from where the milk is bought and sold in local market. Among all the respondents $100 \%$ of the respondents have their own source of milk (buffalo, cow).

\subsection{Problem of Market fee}

Suppliers who need to pay fee to supply milk in the market.

Table 11

Problem of market fee

\begin{tabular}{lcc}
\hline Response & No. of respondents & Percentage \\
Yes & 0 & 0 \\
No & 20 & $100 \%$ \\
Total & 20 & $100 \%$ \\
\hline
\end{tabular}

Sources. Field survey 2019.

Table 11 shows whether the market fee should be paid or not $100 \%$ of respondents said that they should not pay any market fee, the whole area is free for trading.

\section{Findings}

The major findings of the study are presented in bullets form below:

- There are altogether 381 individual families in the village.

- Out of 381 families, 123 belongs to Yadav, 140 belongs to Mandal, 50 belongs to Singh/ Danuwar, 29 belongs to Sharma, 8 belongs to Sah, 10 belongs to Mochi/ Chamar and remaining 21 belongs to Rai family.

- There are total 181 numbers of buffalos and 4 cows in the village.

- Out of 185 , only 54 cows/buffalo give milk till the date. There are approximately 296 liter milks produce daily, out of 296 liter; 171 liter sales by the supplier and remaining 124 used for self-consumption.

- Out of total respondents, $95 \%$ of total respondents agree with the short supply of milk during some time period while remaining, $5 \%$ haven't faced any problem of short supply of fresh milk till the date.

- Out of the total respondents, $80 \%$ of respondents has faced problems of short supply daily, $10 \%$ thrice in a week, $5 \%$ twice in a week, $0 \%$ once in a week and $5 \%$ people has faced the problem rarely on morning.

- Out of the total respondents, $40 \%$ of respondents has faced problems of short supply daily, $15 \%$ thrice in a week, $25 \%$ twice in a week, $15 \%$ once in a week and $5 \%$ people has faced the problem rarely on evening. 
- Among the total respondents, $90 \%$ of respondents do not have any cold storage facility for keeping stock of milk while $10 \%$ of respondents have got the cold storage facility.

- The demand of fresh milk is local market. Among them 55\% of respondents response on high, $25 \%$ response on moderate and $20 \%$ response on low.

- Out of total respondents $60 \%$ people responded as 1 to $3,25 \%$ people responded as 3 to $5,15 \%$ people responded as 5 to 7 and none of them has responded on 7 and above customer visiting this market daily.

- $90 \%$ trader responded dissatisfaction regarding trading area remaining $10 \%$ satisfied with the trading

- Among all the respondents, $100 \%$ of the respondents have their own source of milk (buffalo, cow).

- $100 \%$ of respondents said that they should not pay any market fee, the whole area is free for trading.

\section{Conclusions}

From the findings of the study, it can be concluded that there are less suppliers of milk in compare to total family at the village. There are total of 54 suppliers in the study area as population and only 20 suppliers are selected as respondent.

Research conclude that there occurs short supply of fresh milk during a period of time due to the ineffectively management of milk supply and demand. Some supplier responded that it occurs daily, some responded thrice in week, some responded twice in week, some responded once in week and some responded the rarely faced the problem.

The local demand of milk at this place is usually high. Demand fluctuation occurs time to time in daily basis. In the festival season demand become too higher and the supplier should be prepare for these season. The milk market at the village is very old, the trading space of milk is all free. They don't pay any market fee for the operation of market.

It is gain an understanding of the general behavior of consumer and the marketing trend of milk and its products. The production cost of the small farmers was found to be tentatively higher than of the middle and large farmers. Although different policies have been proposed and implemented for the betterment of commercialization of milk. Seasonal fluctuation of market price for the producers and constant price for the consumers is a major problem. Thus, it can be concluded that the milk supplier of the area are facing the problem of supply fluctuation due to ineffective way of managing the supply and demand of milk. The market is not appropriate for both buyers and sellers.

\section{Policy Implications}

The specific objectives of the study was to analyze the demand and supply status of fresh milk at the area, to identify some of the major problems of milk production and selling situation at 
the selected area. Here it is found that the market place is not appropriate for this market and demand fluctuation occurs in daily basis. The result obtained from this research help to know about the existing problem of milk market of Sohpur village. The existing and upcoming milk traders should come together and maintain a specific place for selling of milk by consulting with local government authorities.

The study has the following policy implications for the related stakeholders:

- The existing suppliers are not focusing on quality of milk. They should try to improve those activities in order to have long term existence in the market. Through improving in timely collecting money, considering hygiene factors and using cows to produce milk rather than buffalos can benefit for the supplier of milk.

- Local government should take proper step for the overall management of the market. The government should have to encourage the people to supply the milk built a specific mechanism for the market, waste management.

- The customer should persuade the supplier through making timely payment of milk.

\section{References}

Adhikari, D. P. (2016). Essential of Business Research Methods. Kathmandu: Asmita books publishier \& distributor.

Australian Government productivity commission. (2014, September). Australian government productivity commission. Retrieved (March 18, 2019), from https://www.pc.gov.au/ inquirieses/completed/dairy -manufacturing/report/dairy-manufacturing.pdf.

Banskota, B. S. (2015). http://lib.icimod.org/reord/21368/files/c_attachment_79_555.pdf. Retrieved 3 20, 2019, from http://lib.icimod.org/reord/21368/files/c_attachment _79_555.pdf.

Food and Agriculture Organization of the United Natons UN Complex, Pulchowk, Nepal. (2010). Dairy Sector study of Nepal. Food and Agriculture Organization, Kathmandu http://en.m.wikipedia.org/wiki/milk. (n.d.). Retrieved (February 28, 2019), from Wikipedia: http://en.m.wikipedia.org/wiki/milk.

khanal, K. (2015). Retrieved 02 25, 2019, from https://kapilkhanal46.wordpress.com.

Lowry, K. (2015). https://www.investopedia.com/terms/c/customer.asp. Retrieved (06 04, 2019) from www.investopedia.comhttps:www.investopedia .com/terms/c/customer .asp.

Shrestha, P. (2071). Fundamental of Selling. Kathmandu: Nabin Prakashan. 
Appendices

A set of question on Milk market at Bariyarpatti, Sohpur

Respected Mr./ Ms./Mrs.

I am the lecturer of Tribhuvan University at Mahendra Morang Adarsha Multiple Campus, Biratnagar, I am conducting research on "Milk Market at Bariyarpatti, Sohpur". So, please separate a few minute of your valuable time to answer the following simple question. I kindly request you to cooperate by responding on the questions. Your answer will be strictly confidential and will be used only for academic purpose:

1. Have you ever faced a problem of short supply of fresh milk? Please tick $(\sqrt{ })$

$$
\text { Yes }
$$$$
\text { No }
$$

2. How often you face short supply of fresh milk in day?

$$
\text { Daily }
$$

Thrice in week

Twice in week

Once in week

Rarely

3. How is the local demand of fresh milk?

$$
\begin{aligned}
& \text { High } \\
& \text { Moderate } \\
& \text { Low }
\end{aligned}
$$

4. Have you got the facility of cold store milk?

$$
\text { Yes No }
$$

5. How many people visit this market daily?

One

Two

Three

Four and above

6. How often you face short supply of fresh milk in night?

Daily

Thrice in week

Twice in week

Once in week

Rarely

7. Are you satisfied with the trading of milk?

$$
\text { Yes }
$$

8. From where you buy milk for trading?

Own source

Other

9. Are you pay for the trading space?

Yes 